\title{
Economic Integration of Aircraft Building Enterprises in the Context of the Transactional Approach
}

\author{
Iryna Kreidych ${ }^{1}$ (), Oksana Kazak ${ }^{2}$ (), Maryna Yanchuk ${ }^{3}$ (D), Inna Milko4 ${ }^{4}$ \\ ${ }^{1}$ National Technical University of Ukraine (Igor Sikorsky Kyiv Polytechnic Institute), Kyiv, Ukraine \\ ${ }^{2}$ Borys Grinchenko Kyiv University, Kyiv, Ukraine \\ ${ }^{3}$ National Aviation University, Kyiv, Ukraine \\ ${ }^{4}$ Simon Kuznets Kharkiv National University of Economics, Kyiv, Ukraine \\ Email: kreidichin@ukr.net,0966220034@ukr.net,milkoinna@gmail.com,kazakoksana1974@gmail.com
}

How to cite this paper: Kreidych, I., Kazak, O., Yanchuk, M., \& Milko, I. (2020). Economic Integration of Aircraft Building Enterprises in the Context of the Transactional Approach. Open Journal of Business and Management, 8, 1252-1273.

https://doi.org/10.4236/ojbm.2020.83081

Received: April 17, 2020

Accepted: May 24, 2020

Published: May 27, 2020

Copyright $\odot 2020$ by author(s) and Scientific Research Publishing Inc. This work is licensed under the Creative Commons Attribution International License (CC BY 4.0).

http://creativecommons.org/licenses/by/4.0/

\begin{abstract}
The theoretical concept of the study of economic integration within the framework of the neo-institutional paradigm is developed. The structure of the transaction costs of a corporation according to the sequence in which they arise during the implementation of transactions is substantiated. The drivers of the integrative development of modern aircraft building enterprises are studied and the content-related basics of their economic integration are formulated. Besides, the necessity of the formation of a mechanism for optimization of transaction costs of economic integration in the context of the transactional approach in the creation of an aircraft building holding company is substantiated. Distinctive and characteristic features of the functioning of aircraft production as a single complex of $\mathrm{R} \& \mathrm{D}$ and batch production that affect transaction costs are singled out and a typology of transaction costs of aircraft building corporations is proposed. A methodical approach to minimizing transaction costs in the creation of an aircraft building holding company is proposed based on the thesis that rational economic integration of aircraft building enterprises is carried out by changing the ownership relations and the transaction system within the framework of the creation of a holding type aircraft building corporation.
\end{abstract}

\section{Keywords}

Economic Integration, Transactional Approach, Minimization of Transaction Costs, Aircraft Building Holding Company 


\section{Introduction}

The purpose of the article is to substantiate theoretical and methodological approaches to the economic integration of aircraft building enterprises in the context of the transaction approach to minimize transaction costs in the creation of a holding type corporation.

The structure of this study is as follows: development of a theoretical concept for studying the integration process; grouping transaction costs; substantiation of the fact that vertical integration of aircraft construction companies is only appropriate between $\mathrm{R} \& \mathrm{D}$ and mass production organizations; development of transaction costs typology; to propose a methodological approach to minimizing the transaction costs of a high-tech corporation and to regulate the transaction costs of an aeronautical holding company.

Modern research reflects the take on the impact of transaction costs on the sustainability of economic development of an enterprise, namely: with the growth of transaction costs, the development slows down, the growth rates decline, the investment and innovative programs of the enterprise are curtailed; there is concealment of income in order to evade taxes and the retreat in the "shadow", which increases the probability of bankruptcy of the enterprise (Yanchuk, 2013). However, on the other hand, low transaction costs lead to lack of competition and investment activity, which adversely affects the product line of high-tech enterprises, in particular of aircraft building ones. Therefore, managing transaction costs of an enterprise in order to reduce them should be aimed at preventing inefficient costs in the process of preparation, implementation and further service of transactions. However, the question of determining the level to which transaction costs should be reduced for each enterprise is individual, and it can be assumed that there is a limit beyond which the positive effect of reducing transaction costs will be canceled out by increased complexity and reduced flexibility of the integrative structure.

The technological basis of economic integration in modern decentralized aircraft building is a fragmented technological chain. Almost none of the world's major aircraft building companies are full-cycle manufacturers (sometimes only for $20 \%-30 \%$ ). Many of them implement an outsourcing model whereby part of the business, including manufacturing, which is contracted to system integrators-carriers of brands that produce final products/services. At present, the drivers of integrative development of aircraft building enterprises are not M\&A processes (though they are possible), but the creation of object-oriented enterprises through fragmentation of technological chains at the expense of the following main components:

- change of design system by integrating design into life cycle management (6D design, simulation design in Simulate-Design-Integrate-Validate version). A single design standard across the entire technology chain enables one to integrate $\mathrm{R} \& \mathrm{D}$, production and service. This integration takes place at various stages; initially, modeling the MIL (Model-in-Loop) or developing 
the SIL (Software-in-Loop) software is carried out; and last, the HIL (Hardware-in-Loop) tests are conducted. Integration of the factory model with the management model or code ensures the necessary precision as well as the availability of variables required for control;

- changing the model of innovation policy by capturing innovation from the outside through coordination of research programs, interaction with independent researchers and developers;

- business process reengineering (outsourcing model, transition from vertical integration to modular supply chain organization). The outsourcing model can significantly reduce the internal transaction costs associated with moving a product within the vertically integrated structure from one process stage to another.

In this case, the formation of a mechanism to optimize transaction costs as a set of methods and tools for managing economic relations between the transaction partners will reduce contract costs through reducing information uncertainty and more rational use of resources and, ultimately, an increase in the profits of participating companies, and, on the other hand, will ensure correct registration of transactions involving the transfer of ownership rights (orders) for acquired resources and the redistribution of residual income rights between the owners.

\section{Literature Review and Research Hypothesis}

\subsection{Neo-Institutional Approach to Economic Integration}

Neo-institutionalism views market mechanism and individual firms from the perspective of contractual relations of economic agents, paying particular attention to the costs and losses that are caused by these relationships. The neo-institutional approach is based on the motivation of institutional transactions in relation to the institutional environment, taking into account clear causal relationships between transaction characteristics and types of institutional system, as A. Shastitko notes (Shastitko, 2010). At the same time, most scholars-S. Arkhiyereev (Arhiereev, 2004), O. Kanischenko (Kanishchenko, 2007), A. Pylypenko (Pylypenko, 2008) (Pylypenko \& Yaldin, 2016), A. Chukhno (Chukhno, 2003), O. Shepelenko (Shepelenko, 2012), I. Yarkayev (Yarkaev, 2007)-associate different institutional forms of economic integration, as a rule, with the following interrelated factors: first, with obtaining synergistic effects as a result of integration; secondly, with reducing transaction costs resulting in increased market competition, reduced risks, dangers, threats, including through diversification, improving production efficiency, expanding markets, attracting investment, that is, improving the efficiency of the economic system itself.

\subsection{Transaction Costs of Integrative Associations}

Studying integration processes by such scientists as Yu. Zvereva (Zverev, 2009), O. Kasatova (Kasatov, 2010), R. Coase (Uilyamson \& Uinter, 2001) (Coase, 1993), 
O. Lisachenko (Lisachenko, 2007) is more focused on solving problems of increasing different kinds of integration effects and practically do not evaluate the cost component of the mechanism of economic integration of enterprises that, in our view, within the neo-institutional paradigm, involves the establishment of clear causal relationships between the characteristics of transactions and the institutional forms of integrative associations at minimal transaction costs.

Familiarization with scientific works about the issue of the feasibility of various forms of integrative transformation of enterprises by domestic scientists P. Buryak (Buriak \& Livinovska, 2010) and A. Mokiy (Mokii, 1999) shows that it is the level of transaction costs that often forms public demand for a particular type and form of corporation and, therefore, the higher the transaction costs, the greater the demand for institutional regulation of innovation in the high-tech sector. Therefore, the choice of a particular institutional form of business model is, first and foremost, determined by the appropriate set of costs.

\section{Research Design}

\subsection{Theoretical Concept of the Study of Integration Processes}

A system concept of economic integration research is presented in Figure 1. In this case, of scientific and practical interest is the need to take into account transaction costs, both market and internal ones, as well as the study of the possibility to regulate and evaluate their impact on the economic performance of the enterprise. In the context of this theoretical concept, the influence of integrative transformations of enterprises on the value of transaction costs is studied. Within the neo-institutional approach, one of the main goals of economic integration of enterprises-minimization of transaction costs-is singled out.

The transactional approach analyzes the "economic aspect of various institutional ways to organize transactions" (Williamson, 1979) and addresses the most important problem of institutional choice-whether individual activities will be carried out through the intermediation of market or through certain institutional forms, since costs (including transactional ones) are systematically changed with the transition from one institutional form of transaction to another one and each type of transaction is implemented within the respective most effective institution. Economic integration in exchange for greater risk security is accompanied by the loss of the function of initiative by individual subjects of the integration, which is not always consistent with the ambitions of their owners. When inconsistency of interests and unequal relations between the participants of an integrative association are present, the internal transaction costs increase; much of these costs are directed to overcoming the opportunistic behavior of participants in the contractual relations (Zamazii, 2006). The introduction of transaction costs into economic analysis was undertaken by R. Coase to explain the existence of such opposing to market "conscious control islands" as firms. In his work, "The Nature of the Firm", R. Coase described transaction costs as "costs of 


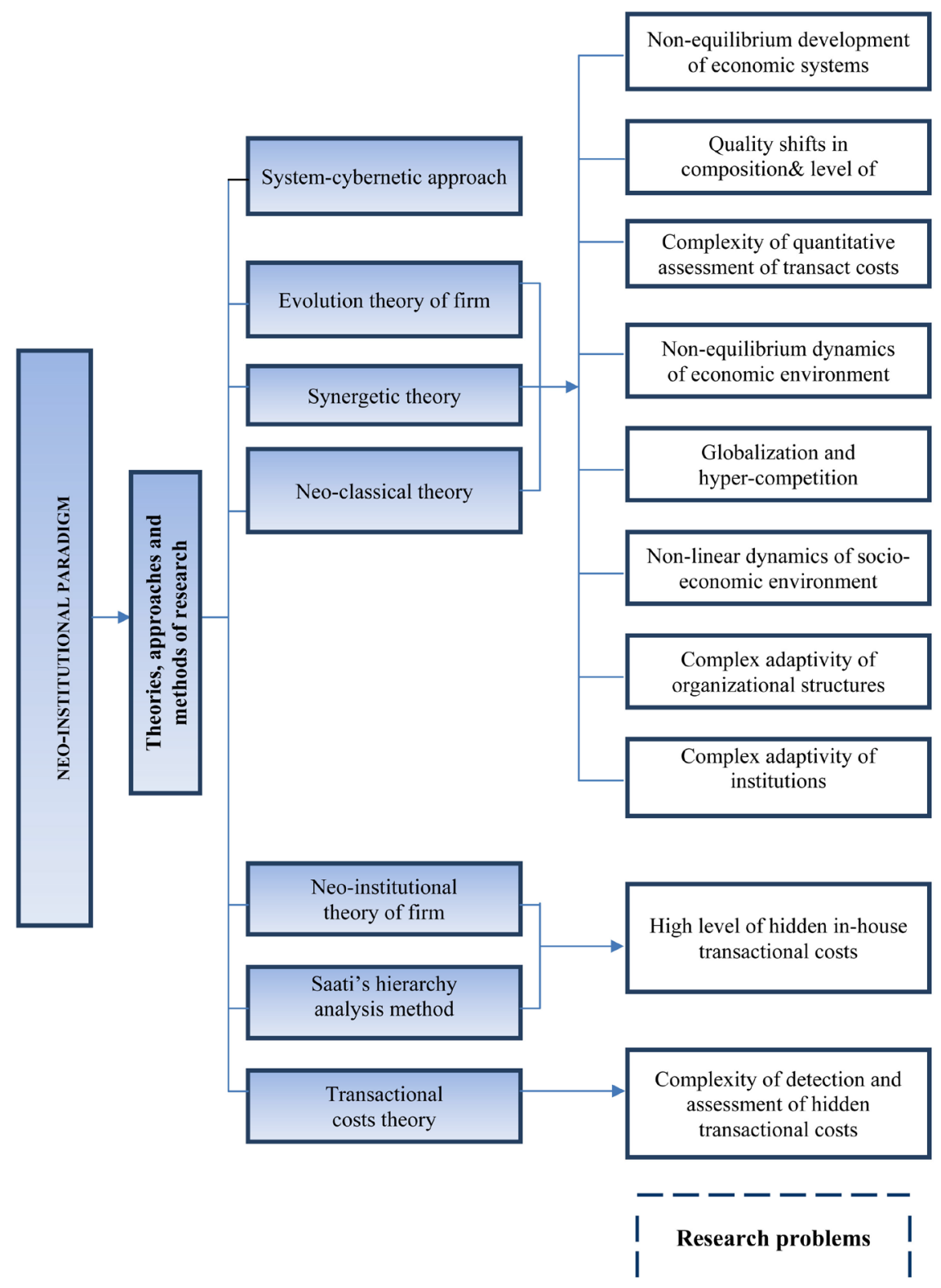

Figure 1. Theoretical concept of the study of integration processes (generalized by the authors based on sources (Kizim, 2000) (Pylypenko, 2008) (Yanchuk, 2013).

using the price mechanism", "conducting open market exchange transactions", or "market costs" (Uilyamson \& Uinter, 2001).

Later, in his article "Problems of Social Costs", R. Coase used the expression "costs of market transactions". He described their essence as follows: "in order to carry out a market transaction, it is necessary to determine with whom it is desirable to enter into an agreement, to inform everyone with whom they wish to enter into the agreement and on what terms, to hold preliminary negotiations, to prepare the contract, to gather information to make sure that the conditions of the contract are fulfilled..." (Coase, 1993). However, in economic terminology, the expression "transaction costs", which is also found in R. Coase's works, has 
been accepted and has become widespread; its meaning is the following: transaction costs (agreement costs) are the costs of gathering and processing information, negotiation and decision-making, control and legal protection of contract performance; and according to the definition of $\mathrm{O}$. Williamson, transaction costs are costs related not to the production process, but rather to the relationship between the economic agents (Uilyamson, 1996).

\subsection{Problems of Estimating and Managing Transaction Costs of Aircraft Companies}

As for solving the problems of estimating and managing the transaction costs of aircraft building companies, we take the view that, in methodological terms, it is advisable to group them by the sources of origin and the stages of conclusion, implementation and closing of the contract, that is, it is necessary to take into account such features as the changing of the composition of costs ex ante (before concluding agreements/contracts) and ex post (after concluding the agreement) (Table 1).

We agree with S. Belchenko's view (Belchenko, Halikov, \& Schepilov, 2011) that intra-firm (in-house) transaction costs, which are connected with the coordination, planning and management of the production and investment activity, correspond to their external analogues insofar as in-house mechanisms of managing structural divisions of the enterprise that form its organizational structure repeat the mechanisms of interaction of independent entities in open markets.

In this context, it should be noted that these conditions are of particular relevance for the process of economic integration of aircraft building enterprises which can be considered as the value creation chain of a high-tech product

Table 1. Grouping transaction costs before and after the conclusion of transactions.

\begin{tabular}{|c|c|}
\hline $\begin{array}{l}\text { EX ante costs } \\
\text { (before the conclusion of the agreement) }\end{array}$ & $\begin{array}{l}\text { Ex post costs } \\
\text { (after the conclusion of the agreement) }\end{array}$ \\
\hline $\begin{array}{l}\text { Information search costs: costs of finding } \\
\text { information about a potential partner and market } \\
\text { situation; losses due to incompleteness and } \\
\text { imperfection of the information received. }\end{array}$ & $\begin{array}{l}\text { The costs of monitoring and preventing } \\
\text { opportunism: the costs of monitoring the } \\
\text { compliance with the terms of the agreement } \\
\text { and preventing opportunism } \\
\text { (evasion of these terms). }\end{array}$ \\
\hline $\begin{array}{l}\text { Negotiation costs: the costs of negotiating } \\
\text { the terms of the exchange and the } \\
\text { choice of the form of the agreement. }\end{array}$ & $\begin{array}{l}\text { The costs of specification and protection } \\
\text { of property rights: the costs of arbitration; } \\
\text { the costs of time and resources required } \\
\text { to restore the rights violated during } \\
\text { the performance of the contract. }\end{array}$ \\
\hline $\begin{array}{l}\text { Shortcomings of measurement: costs required } \\
\text { to measure the quality of the goods and services } \\
\text { that make up the content of the agreement } \\
\text { Third party protection costs } \text { costs of } \\
\text { protection from third party claims for } \\
\text { part of the beneficial effect of the transaction }\end{array}$ & $\begin{array}{l}\text { Third party protection costs: costs of } \\
\text { protection from third party claims for } \\
\text { part of the beneficial effect of the transaction }\end{array}$ \\
\hline
\end{tabular}

Note: compiled through summarizing sources (Shastitko, 2010) (Yarkaev, 2007). 
which includes the R\&D stage, the stage of component production, final product preparation, marketing and sales as well as service. Therefore, in this context of research, it would be appropriate to use the definition of "transaction" in high-tech production proposed by $\mathrm{O}$. Williamson-as "the transition of a product or service from the end point of one technological process to the starting point of another one, adjacent to the first one" (Uilyamson, 1996).

\subsection{The Specificity of Assets as the Most Important Factor of Economic Integration}

According to the transaction cost theory, the most important factor of economic integration is asset specificity, that is, the ability of assets to provide the greatest benefit only with a specific transaction; these assets are the embodiment of a specialized investment and cannot be repurposed for alternative uses or alternative users without losses in their production potential. The specificity of assets can take several forms, among which the main are the specificity of human capital, fixed assets, location as well as targeted assets: narrow specialization of equipment with which products are produced; proximity to the location of adjacent production facilities; the presence of complementary specialization of the workforce and established cooperation in the field of innovation, etc. In this case, the following pattern holds: the higher the specificity of assets, the greater the economic integration (Uilyamson, 1996).

Applying these concepts of the transaction cost theory to aircraft building enterprises characterized by highly specific assets, one can say that, to reduce transaction costs, they classically initiate mergers with vertical integration counterparties (material suppliers, unit and component manufacturers, final product assemblers, sellers and end-product consumers).

However, given the current departure in the high-tech sector from the closed-cycle technology model towards cycle virtualization, we believe that vertical integration of aircraft building enterprises is only advisable between R\&D entities and serial manufacturers. Therefore, we believe that in assessing the magnitude and causes of the formation of transaction costs it is desirable to analyze both the degree of specificity of assets and the integrative nature of a particular production process.

The basis of the analysis of transactional specificity of assets is technological specificity, which gives the opportunity to solve the problem of vertical integration of enterprises in attracting assets or specific investments of different forms of ownership, which allows ensuring the production of products along the entire chain of research-production-sales cycle with minimal costs and, above all, transaction ones.

The study of the economic aspects of integration in the high-tech sphere testifies to the validity of today's main hypothesis of the transaction cost theory formulated subsequently by $\mathrm{O}$. Williamson: "when a transaction occurs in the context of high uncertainty and specificity of capital/assets as well as of high fre- 
quency of repeated transactions, a 'dip' of the market occurs, and firms tend to resort to vertical integration” (Shastitko, 2010).

\subsection{Features of the Functioning of Aircraft Companies and Their Impact on the Value of Transaction Costs}

Some scientific studies reflect such a view that the value of transaction costs affects the sustainability of the economic development of the enterprise: with an increase in the transaction costs, the development slows down, the growth slows down, the investment and innovation programs of the enterprise are curtailed, there is concealment of income in order to evade taxes and the retreat in the "shadow", which increases the probability of bankruptcy of the enterprise (Shepelenko, 2012).

However, on the other hand, low transaction costs lead to lack of competition and investment activity, which adversely affects the product line of a high-tech enterprise. Therefore, it should be remembered that management of the transaction costs of an enterprise in order to reduce them should be aimed at preventing inefficient costs in the process of preparation, implementation and further service of transactions. But the question of determining the level to which transaction costs should be reduced for each enterprise is individual, and it can be assumed that there is a limit beyond which the positive effect of reducing transaction costs will be cancelled out by increased complexity and reduced flexibility of the integrative structure.

The peculiarity of organization of aircraft building production is that it is a single complex of scientific search, experimental design, engineering solutions, preparation of pilot production and, finally, batch production with the direct bringing of created products to the end consumer (Bielov, 2011). One should mention the following distinctive and characteristic features of the operation of aircraft building enterprises that affect the amount of transaction costs:

- effective system of protection of intellectual property rights and dissemination of innovations;

- high dynamism of production, which is manifested in the constant restoration of its elements (objects of research, development and production, technologies, schema and design solutions, information flows, etc.), in the change of quantitative and qualitative indicators, in the improvement of the scientific and industrial structure and the management system;

- ability to actively and effectively invest and innovate, high specific R\&D costs in the structure of production costs;

- improvement of the pricing system, which is to account for all production costs including the costs of $R \& D$, the system of management of innovative projects, the system of education and training of employees, etc. (Krivyakin, 2012) (Salikhova, 2012).

Accordingly, we view the economic integration of modern aircraft building enterprises as an effective interaction between the state of connectedness of in- 
dividual enterprises and the process which leads to the optimization of relations between them in integrating them into an integrative system of new quality and new potential opportunities with minimal transaction costs.

\subsection{Typology of Transaction Costs of Aircraft Building Corporations}

In the context of the already described significant change in the technological basis of integration of aircraft building enterprises, the most relevant thing today is the context of integration research with recognition of the increasing growth of the dependence of economic results of their research and production activity on the level of transaction costs as regulators of modern integrative transformations. It should be noted that, from a methodological point of view, economic integration is a relevant strategy for the development of aircraft building enterprises in order to improve their production efficiency and their sustainability in the global market.

Therefore, based on the study and generalization of opinions of the above domestic and foreign scientists, we provide a typology of transaction costs, which takes into account the nature of the activity of aircraft building corporations (Table 2).

Thus, scale-up of business through the creation of a corporate structure puts out the market and requires the establishment of a single business management system along the entire technological chain, which becomes more efficient in the case of saving transaction costs within the framework of a newly formed corporation compared to similar market operations. Concentration and pooling of resources lead to significant saving due to the scale of activities, which, in turn, contributes to the reduction of fixed transaction costs per unit of output.

Practical experience shows that the processes of the increasing of transaction costs, in turn, stimulate the emergence of companies, and on the scale of economic systems-of branches of science, on the basis of which transaction management is accompanied. The practice of companies in the market shows that the increase in transaction costs for marketing activities, the maintenance of the administrative apparatus, the services of accountants and lawyers can exceed the cost of creating the product and adversely affect the pricing policy of economic entities, reduce the efficiency of production and sales of products, jeopardize their financial stability and competitiveness.

The conducted study allowed us, in the methodological dimension, to present the content basics of the economic integration of aircraft building enterprises within the framework of the theoretical concept of the neo-institutional paradigm developed above, the main ones being the following:

- modern integration is based on the coordination of the purpose, actions, economic interests of the enterprises, on the understanding of the necessity and profitability of the association;

- integration takes place in the form of contracts that partially replace or completely supplant the market price mechanism; 
Table 2. Typology of transaction costs of aircraft building corporations (compiled by the authors).

\begin{tabular}{|c|c|}
\hline Types of costs & Content \\
\hline $\begin{array}{l}\text { The costs of } \\
\text { finding information }\end{array}$ & $\begin{array}{l}\text { Difficulties in accessing information (the required development can } \\
\text { often be performed only at a limited number of research organizations), } \\
\text { assessing and selecting the most promising solution from the possible } \\
\text { ones. As the volume of information increases and its complexity } \\
\text { becomes greater, it becomes more difficult to process available data, } \\
\text { which causes spending considerable time and financial resources } \\
\text { for studying and finding the technology needed by the enterprise, } \\
\text { finding partners for an innovative project. }\end{array}$ \\
\hline $\begin{array}{c}\text { Costs of } \\
\text { contracting }\end{array}$ & $\begin{array}{l}\text { Based on the essence of technology, it is clear that the exchange } \\
\text { participants discuss many conditions, determine the price of knowledge } \\
\text { transferred, the mechanism of commercialization of technology. } \\
\text { Often, the relationship of the parties to the agreement is not limited to } \\
\text { the mere transfer of intellectual property rights. Therefore, } \\
\text { negotiating and contracting costs much higher than, for example, } \\
\text { the regular purchase of non-specific goods. }\end{array}$ \\
\hline $\begin{array}{l}\text { Shortcomings } \\
\text { of measurement }\end{array}$ & $\begin{array}{l}\text { Absence of market price for a new solution. Uncertainty and likelihood } \\
\text { of errors in determining the expected commercial outcome of the } \\
\text { introduction of new technologies. The need for a new product } \\
\text { does not guarantee the success of the innovation. In many cases, } \\
\text { it is difficult to directly measure the characteristics of a technology, } \\
\text { such as the physical properties of a fundamentally new product. }\end{array}$ \\
\hline $\begin{array}{c}\text { Costs of } \\
\text { opportunistic } \\
\text { behavior } \\
\text { of the overall result }\end{array}$ & $\begin{array}{l}\text { Distortion of information in the technology market for intentional } \\
\text { misrepresentation, breach of agreement. Opportunism can manifest } \\
\text { itself both before the conclusion of a contract (for example, by not } \\
\text { providing all the relevant data and characteristics of the invention, } \\
\text { or by exaggerating its advantages and concealing its disadvantages) } \\
\text { and in the process of introducing R\&D results in production (in many } \\
\text { cases, parties tend, above all, to maximize their own profit rather than } \\
\text { to take all the necessary steps to achieve a better overall result). }\end{array}$ \\
\hline
\end{tabular}

- decisive influence of government regulation on reducing transaction costs through the formation of an appropriate institutional environment (the formation of the legislative framework of executed agreements, the level of confidence of economic agents).

\subsection{A Methodical Approach to Minimize Transaction Costs}

In the context of the transactional approach, we propose a methodical approach to minimize transaction costs (TC) in the creation of an aircraft building holding company based on the thesis that rational economic integration of aircraft building enterprises is carried out by changing the relationship of ownership and the transaction system within the framework of the formation of a quasi-integrative aircraft building structure (QAS) (Figure 2). According to the proposed methodology, the possible choice of organizational integrative structure based on the criterion of the level of transaction-relatedness of costs of different types of corporations is, by and large, due to the need to increase profit while reducing/optimizing transaction costs, and can be determined by the following 


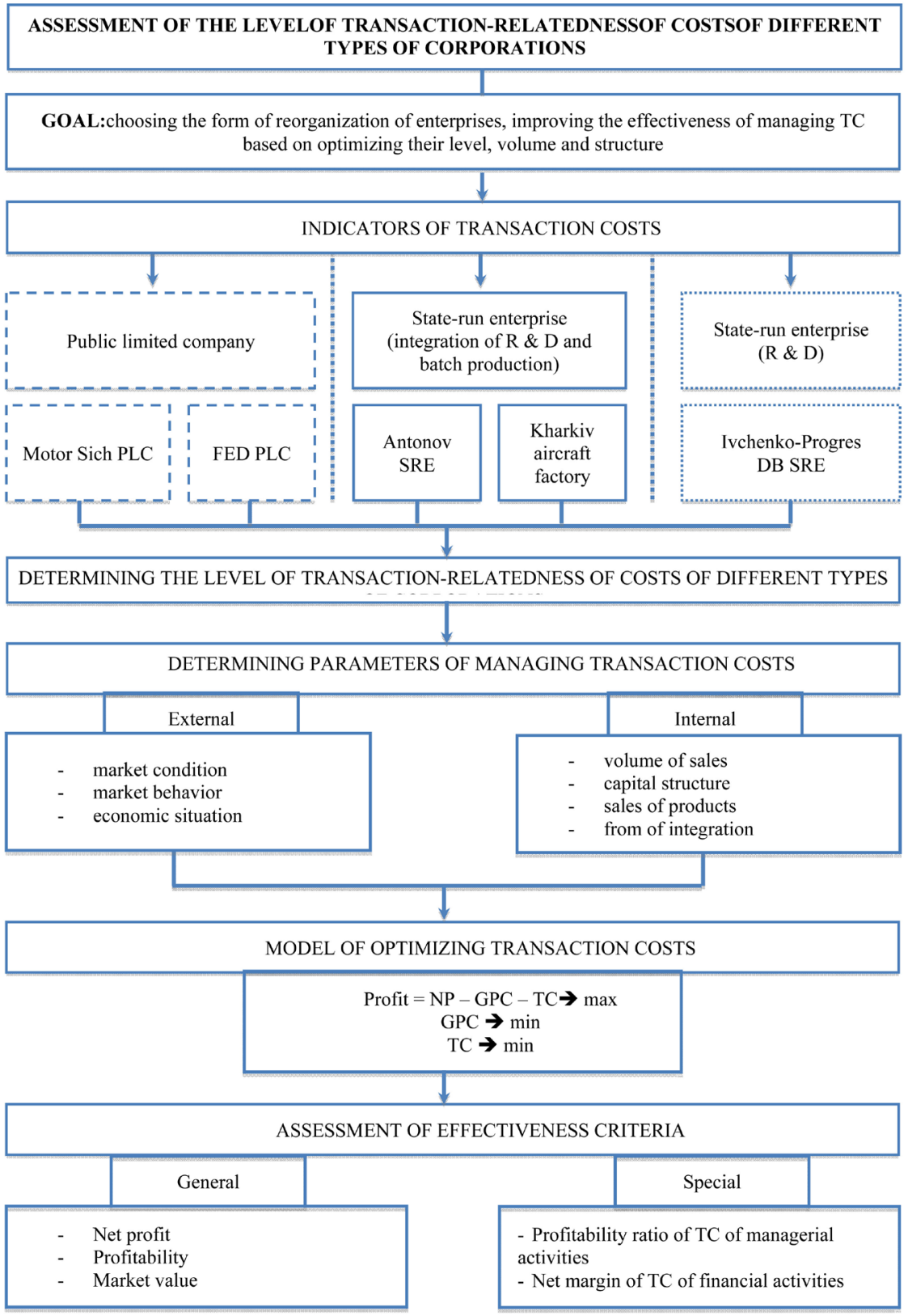

Figure 2. Methodical approach to the assessment of the level of transaction-relatedness of costs of aircraft building enterprises in choosing the form of reorganization.

logical model: $\mathrm{P}=\mathrm{NP}-\mathrm{GPC}-T C \rightarrow \max$. Since profit maximization, as a systemic effect of economic integration of enterprises, should be ensured through optimization of both transaction and general production costs, it is advisable to supplement this logical model with the following criteria: GPC $\rightarrow$ min, $T C \rightarrow \min$. Therefore, the model of transaction cost optimization will have the expression: $\mathrm{P}$ $=\mathrm{NP}-\mathrm{GPC}-T C \rightarrow \max , \mathrm{GPC} \rightarrow \min , T C \rightarrow \min$, where $\mathrm{P}$ is profit; $\mathrm{NP}-$ net profit; GPC - general production costs; $T C$ - transaction costs.

The formation of an open model of object-oriented aircraft building production as a promising basis for ensuring a complete cycle of aircraft production 
within the framework of QAS is connected with such institutional transformations as: the substitution of the joint stock form of ownership for the state one, the emergence of corporate relations, the formation of contracting system based on multilevel quasi-integrative ties related to executing outsourcing and subcontracting operations, which objectively leads to the emergence of new transactions of aircraft building companies and, accordingly, to the expanding of the typology of transaction costs. In this case, an aircraft building holding company as an active company and main system integrator of a quasi-integrative aircraft building structure expands both external transactions, which are related to simultaneous participation in various aircraft building projects, and internal transactions that arise in the formation of an effective contracting system based on multilevel quasi-integration ties within the QAS as a novel economic unit of an open model of aircraft building production, which, as a product of scientific work, are presented by us in Figure 3 and in Table 3.

In addition, both types of transactions involve the costs of opportunistic treatment of external and internal business counterparties, which significantly complicate the processes of their internal and external integrative interaction in

Table 3. Composition of transaction costs of a newly created aircraft building holding company in the context of an open model of aircraft building production (developed by the authors).

\begin{tabular}{|c|c|c|c|}
\hline \multicolumn{2}{|c|}{$\begin{array}{l}\text { An operating state-owned } \\
\text { aircraft building enterprise }\end{array}$} & \multicolumn{2}{|c|}{$\begin{array}{l}\text { A newly created aircraft } \\
\text { building holding company }\end{array}$} \\
\hline Internal TC of: & External TC of: & Internal TC of: & External TC of: \\
\hline $\begin{array}{ll}\text { - } & \text { internal turnover, } \\
\text { - } & \text { energy service, } \\
\text { - } & \text { mechanical repairs, } \\
\text { - } & \text { carrying out research, } \\
\text { - } & \text { information support, } \\
- & \text { functioning of the } \\
\text { enterprise performed } \\
\text { by internal units. }\end{array}$ & $\begin{array}{l}\text { - } \quad \text { marketing; } \\
\text { - } \quad \text { negotiating and contracting; } \\
\text { - } \quad \text { protecting against } \\
\text { opportunistic behavior; } \\
\text { - costs related to the protection } \\
\text { of brands, trademarks, } \\
\text { intellectual property; } \\
\text { costs associated with } \\
\text { engaging with suppliers } \\
\text { and buyers in the market. }\end{array}$ & $\begin{array}{l}\text { - } \\
\text { elaboration of organizational } \\
\text { project and its coordination } \\
\text { with experts and departments; } \\
\text { - } \text { formation of the } \\
\text { management company; } \\
\text { deployment of the corporate } \\
\text { communication system; } \\
\text { reorganization, implementation } \\
\text { of a new system of standards, } \\
\text { reporting, management; } \\
\text { management; } \\
\text { upkeep of the management } \\
\text { personnel of the } \\
\text { integrated structure; } \\
\text { creation of a unified system } \\
\text { of research and development } \\
\text { in the integrated company; } \\
\text { creation of a unified system of } \\
\text { accounting, reporting, finance; } \\
\text { creation and management } \\
\text { of a single distribution network. }\end{array}$ & 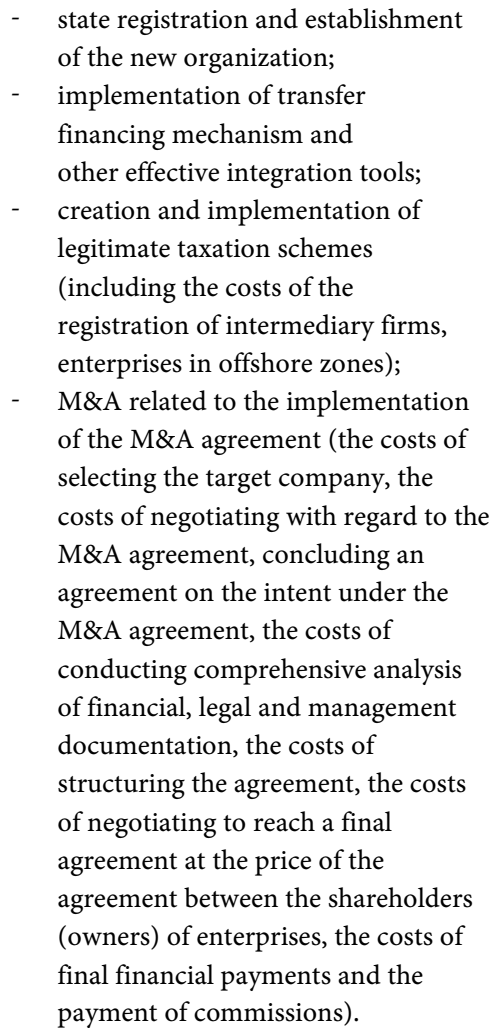 \\
\hline
\end{tabular}




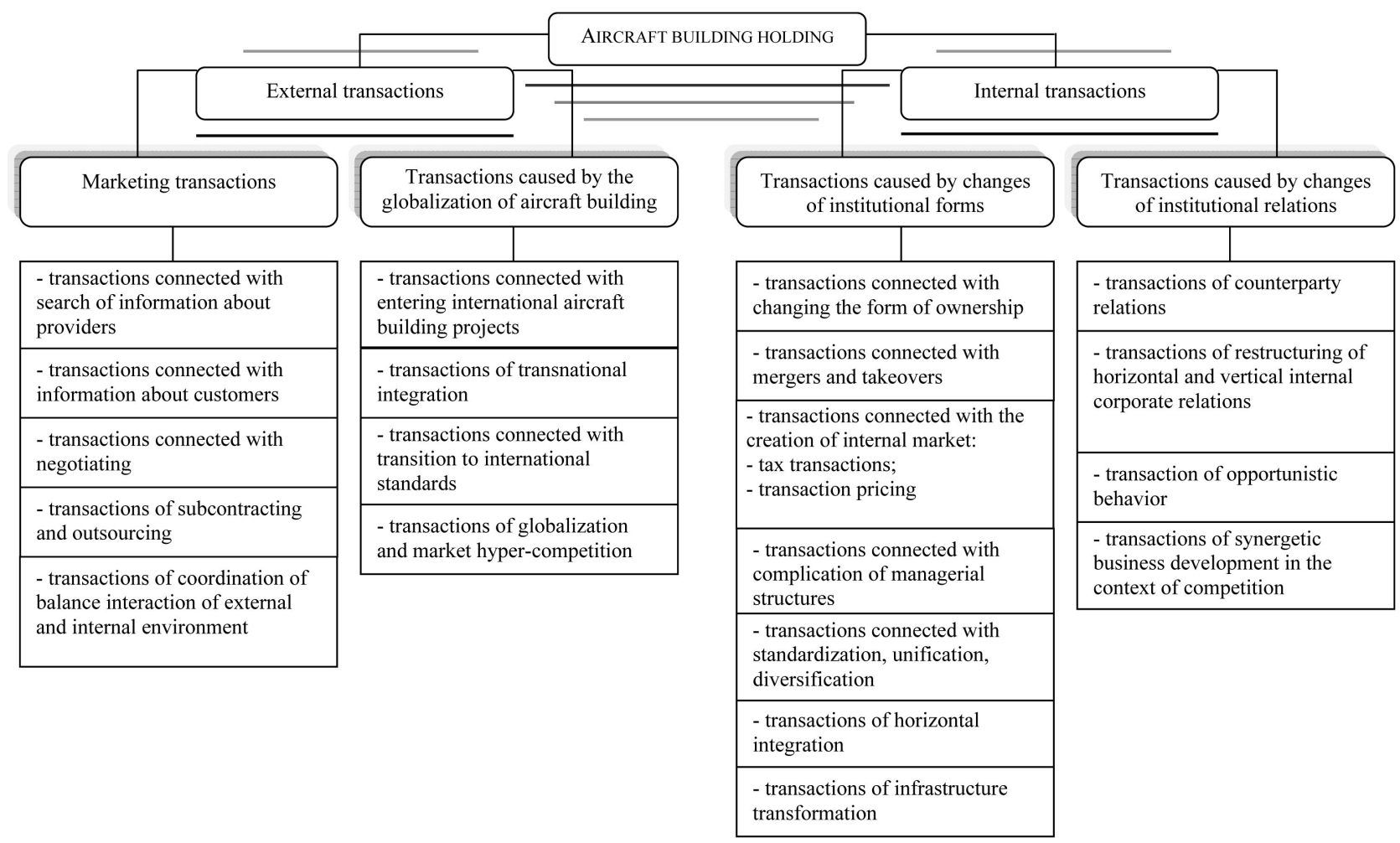

Figure 3. Transactions of an aircraft building holding company as an active company and main system integrator of QAS (developed by the authors).

the context of the open aircraft building model. It should be noted that, in this case, in the composition of transaction costs, one should take into account costs which by their nature are ones of collective action and are aimed at maintaining the institutional equilibrium in the economic system.

The level of transaction costs influences the end result of the functioning of a newly created aircraft building holding company, namely: the lower it is, the better it functions and the higher the degree of consistency of the participating companies

$$
\begin{gathered}
T C_{\text {intern }} / S=n_{1} N \\
T C_{\text {extern }} / S=-n_{2} N+d,
\end{gathered}
$$

where:

$n_{1}$ is the coefficient that characterizes the rate of increase of internal transaction costs;

$N$ is the number of enterprises in an integrated industrial structure;

$T C_{\text {intern }}$ are internal transaction costs of an integrated industrial structure, $\mathrm{UAH}$;

$T C_{\text {extern }}$ are transaction costs relating to external economic communications, $\mathrm{UAH}$;

$S$-sales volume, UAH,

$n_{2}$ is the coefficient characterizing the rate of decrease in transaction costs re- 
lating to external economic communications, depending on the increase in the number of management objects;

$d$ is a free member of the equation showing the amount of transaction costs relating to external economic communications at $N=0$ (for convenience-fixed costs relative to the size of an integrative aviation industry structure).

The coefficients $n_{1}$ and $n_{2}$ in the equations and the corresponding optimal values of $N, T C_{\text {intern }}$ and $T C_{\text {extern }}$ are determined by solving linear equations. The optimization criterion, as already stated, is the equality of transaction costs of $T C_{\text {intern }}=T C_{\text {extern }}$

\subsection{T. Saaty's Hierarchy Analysis Method for Estimating Hidden Transaction Costs}

To assess hidden transaction costs, we have chosen such a mathematical tool for a systematic approach to complex decision-making problems as T. Saaty's Hierarchy Analysis Method (HAM), according to which the assessment of the transaction costs of the process of the creation of an aircraft building holding company is presented as a hierarchical structure, the vertex of which is the main goal; the low level elements represent many options for achieving the goal (alternatives); the elements of the intermediate levels meet the criteria or factors that associate the goal with the alternatives.

Therefore, according to the HAM methodology, the weights of the importance of individual categories of transaction costs (as a rule, hidden ones) are determined using special computer programs (Expert Choice, Super Decisions) in two stages:

1) In the first stage, the weights of importance of each transaction cost type are determined; the results are summarized in Table 4.

The hierarchy of external transaction costs of the process of creating an aircraft building holding company to determine the weight of each component will consist of three levels (Figure 4).

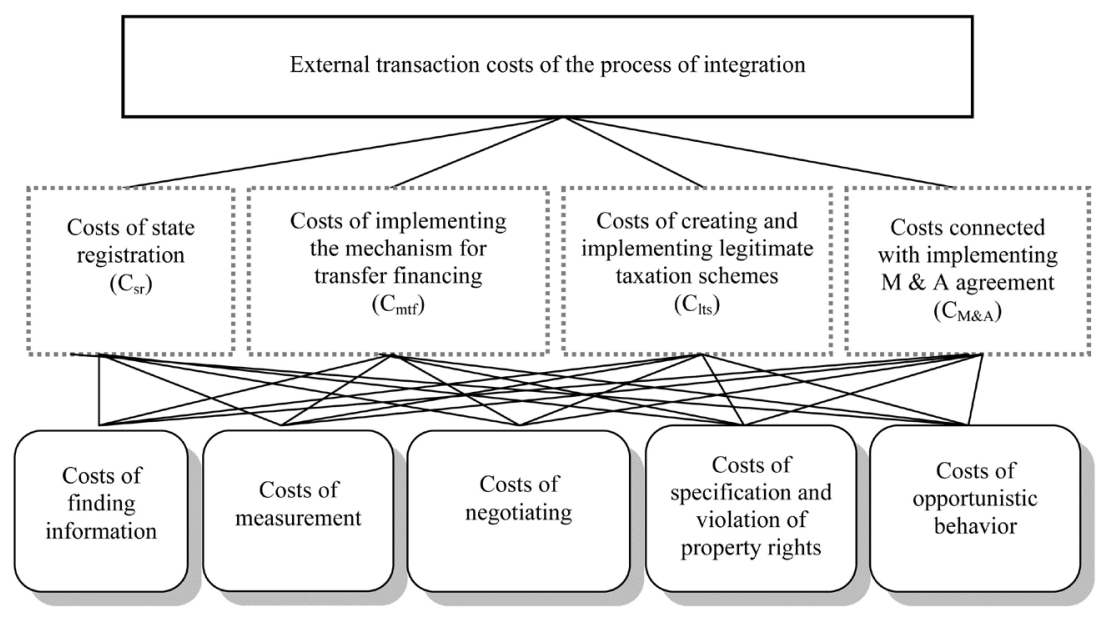

Figure 4. The hierarchy of external transaction costs of the integration process (developed by the authors). 
Table 4. The weights of importance of the hidden transaction costs of the operation of an aircraft building holding company.

\begin{tabular}{|c|c|}
\hline Type of costs & Weight of importance \\
\hline \multicolumn{2}{|l|}{ Transaction costs of the sale of aviation products. } \\
\hline Costs of opportunistic behavior & 0.188 \\
\hline Costs of negotiating & 0.203 \\
\hline Measurement costs & 0.156 \\
\hline Costs of property rights specification and protection & 0.243 \\
\hline Costs of finding information & 0.205 \\
\hline \multicolumn{2}{|l|}{ Costs of opportunistic behavior. } \\
\hline Evasion & 0.143 \\
\hline Extortion & 0.264 \\
\hline Costs of organization of control & 0.377 \\
\hline Contract breach risk insurance & 0.214 \\
\hline \multicolumn{2}{|l|}{ Costs of specification and protection of property rights. } \\
\hline Costs of litigation & 0.202 \\
\hline Licensing costs & 0.186 \\
\hline Costs of counseling & 0.274 \\
\hline Fines. penalties & 0.332 \\
\hline \multicolumn{2}{|l|}{ Negotiating costs: } \\
\hline Costs of negotiating & 0.151 \\
\hline Costs of entering into agreements & 0.165 \\
\hline Costs of registration of contracts & 0.208 \\
\hline Loss due to unsuccessful contracts & 0.245 \\
\hline Loss due to poorly registered and unsecured transactions & 0.230 \\
\hline \multicolumn{2}{|l|}{ Measurement costs: } \\
\hline Costs of measuring the quality of products & 0.249 \\
\hline $\begin{array}{l}\text { Costs of purchasing measuring instruments } \\
\text { to evaluate the quality of products }\end{array}$ & 0.402 \\
\hline Loss due to poor quality measurement & 0.352 \\
\hline \multicolumn{2}{|l|}{ Costs of finding information: } \\
\hline Spending time for finding information & 0.207 \\
\hline Spending money for finding information & 0.303 \\
\hline Losses due to incompleteness of information & 0.248 \\
\hline Losses due to inaccuracy of information & 0.246 \\
\hline
\end{tabular}

Note ${ }^{*}$ calculated using super decisions.

2) In the second stage, an appropriate hierarchy is drawn up to determine the importance of the individual components of each transaction cost category. In 
this case, the hierarchy is presented by us as an example of the costs of the opportunistic behavior of suppliers, since their independence within a quasi-integrative aircraft building structure creates the risk of violating the principles of business ethics and their opportunistic behavior (Figure 5).

Generalizing the methodology of assessing the transaction costs in the creation of an aircraft building holding company, we can single out its following stages.

In the first stage, it is necessary to determine the list of available accounting documents at the enterprise, by which it is possible to determine the individual transaction cost categories of the integration process and the method of accounting.

\subsection{Estimation of Dynamics of Expenses for Scientific and Technical Sphere}

We believe that in the composition of costs of a high-tech corporation, in particular, an aircraft building one, an important place is occupied by the costs of scientific and technological sphere with the characteristics of transactional load. The assessment of their dynamics can be determined on the basis of the analysis of such a statistical form of reporting of the State Statistics Committee as "Innovation"-form \#1, which gives an opportunity to analyze the following types of costs:

- search for developers and concluding works contracts;

- acquisition of rights to patents and licenses for industrial property objects;

- acquisition of technology solutions obtained outside the enterprise (patent-free licenses, know-how's, technologies, etc.), or acquisition of R\&D results;

- marketing and advertising;

- other costs (technical training, instruction in the conditions of the enterprise and others); as well as on the basis of the analysis of such a statistical form of reporting of the State Statistics Committee of Ukraine as "Science"-form $\# 1$.

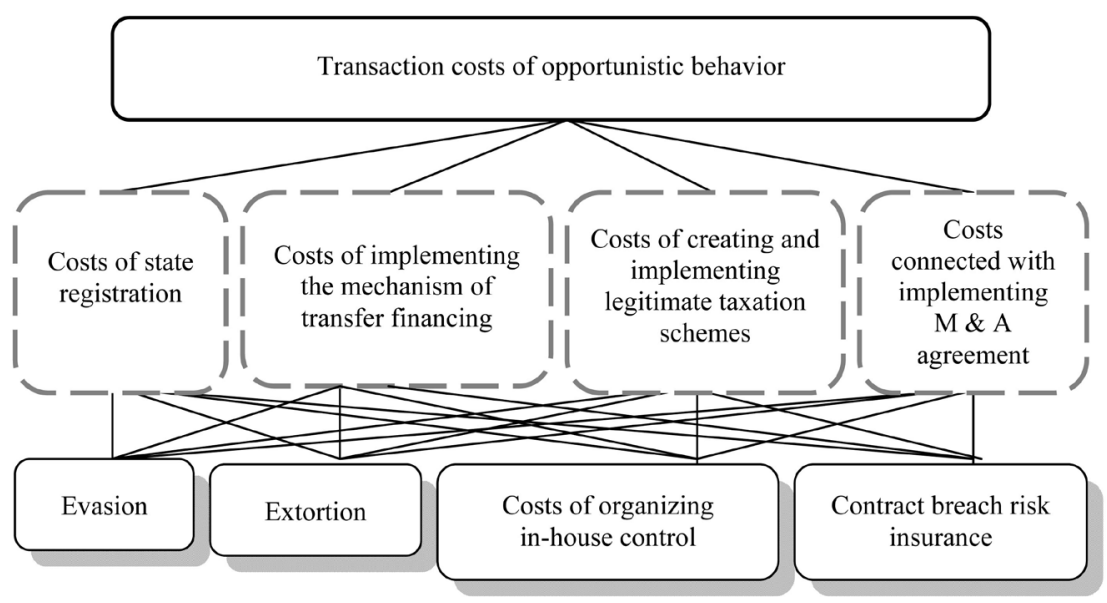

Figure 5. The hierarchy of costs of opportunistic behavior (developed by the authors). 
This statistical reporting provides an opportunity to analyze the dynamics of costs according to the item "The volume of scientific and technical services" in the composition of indicators of the total cost of scientific and technical works performed by scientific-design structures themselves: the costs of scientific and technical information, patents, licenses, scientific and technical consulting, introduction activities, other activities that contribute to the acquisition and use of scientific knowledge. It is recommended to evaluate the detailed nomenclature of transaction costs, their level and dynamics at the corporate level, taking into account the capabilities of the existing information-statistical and accounting reporting.

Using this classification, one can analyze, evaluate, change the relationship between individual items of costs in accordance with the rules of management accounting and controlling. In our view, accounting for transaction costs in the context of an open aircraft building model will allow to fully assess the effectiveness of the process of creating an aircraft building holding company, taking into account all internal and external transactions in the context of an open aircraft building production model.

In the second stage, on the basis of accounting documents, one should single out the top-priority categories of transaction costs which ensure the adequacy and higher accuracy of calculations (costs of specification, protection of property rights, measurement and information retrieval).

In the third stage, using the principle of mathematical proportion, we find the weight value of the categories of hidden transaction costs in an indirect way using HAM.

In the fourth stage, as a result of the calculations conducted, it is possible to obtain several different values of the same type of transaction costs. And, in this case, it is necessary to find the average value, which will be the one to which the calculations were directed.

This method of assessing the transaction costs of the integration process allows to obtain quantitative values of each category of the transaction costs of the process of the creation of an aircraft building holding company. In this case, in this method, both the direct method of accounting based on available accounting data and the indirect method of accounting based on HAM are used.

Thus, as for the process of optimizing the creation of an aircraft building holding company as the main system integrator based on the criterion of minimal transaction costs, we propose the following:

- minimizing the transaction costs associated with seeking information about counterparties, pricing and other possible terms of a transaction;

- reducing the production and sales costs through closer cooperation with counterparties and within the integrated structure;

- cost savings due to the closeness of information interaction, the expansion of the information base, the overcoming of uncertainty in the external environment; 
- reducing the transaction costs of opportunistic behavior by developing standards of management, quality control and legal regulation of corporate ownership;

- minimizing lost profits;

- consolidating resources for $\mathrm{R} \& \mathrm{D}$ and the development of new products;

- researching markets of raw materials, characteristics of manufacturers;

- using alternative mechanisms to ensure the system of internal contracts;

- optimizing the organizational structure, developing a unified strategy and tactics of the development of the integrated structure;

- reducing marketing costs by creating a unified marketing and advertising service.

Thus, in the creation of an aircraft building holding company, savings can be ensured by: successful implementation of long-term contracts concluded between production, financial and marketing structures; effective functioning of the actual aircraft building holding company as the main company which ensures centralization of general corporate functions; through the introduction of a general information-analytical system, which significantly speeds up information exchange and openness between the members of the association.

\subsection{Cost Optimization Based on the SPP Models}

In the creation of an aircraft building holding company, a major role is played by the high specificity of aircraft building assets which necessitates rigid vertical integration of the enterprise that develops and designs aircraft and components with batch production enterprises, while ensuring the reduction of transaction costs by cancelling out opportunistic behavior and problems within the framework of the single entity. In this case, the use of specific assets of different forms of ownership (based on SPP (state-private partnership) models) will allow optimizing both transformational and transactional costs for all stages of aircraft building production: the design, the production and the sales ones.

It is proposed to regulate the values of the transaction costs of an aircraft building holding company as the main system integrator in two main areas:

1) in the internal environment-by determining the rational scale of market activity, increasing controllability by implementing a cost management system and developing a unified policy - the rules of behavior of the subject. Within this area, we propose a methodical approach for locally calculating the impact of transaction costs on the effectiveness of contractual transactions based on the estimation of break-even threshold for marginal income by correlating the latter with the amount of external and internal transaction costs:

$$
E=\frac{P_{m}}{C_{\text {extern }}+C_{\text {intern }}+C_{\text {other }}} \cdot 100 \%
$$

where:

$E$ is the economic effectiveness of transaction costs, \%; 
$P_{m}$ is the projected marginal profit of a separate contract, UAH;

$C_{\text {extern }}, C_{\text {intern }}, C_{\text {other }}$ are the external, internal and other transaction costs of the contract.

[As the above formula is not editable, the letters therein should be replaced by, respectively, $E, P_{m}, C_{\text {extern }}, C_{\text {intern }}, C_{\text {other }}$-translator's note].

In this case, special attention should be paid to the costs of opportunistic behavior and of the influence of own share of capital in the total capital of the aircraft building holding company, which make up a significant share in the total costs, first of all, of investment and innovation activity, as well as of production.

As a relative indicator of the efficiency of economic integration of aircraft building enterprises on the criterion of transaction costs, it is proposed to use the factor of the efficiency of the process of integration of aircraft building companies according to the formula:

$$
E_{i}=\frac{P_{i}}{T C}
$$

where:

$E_{i}$ is the efficiency of the integration process;

$P_{i}$ is the profit from the integration, $\mathrm{UAH}$;

$T C$ is the transaction costs of the integration process, $\mathrm{UAH}$.

[As the above formula is not editable, the letters therein should be replaced by, respectively, $E_{p}, P_{p}, T C$-translator's note].

Thus, to summarize, the economic efficiency of the process of integration of aircraft building enterprises in the context of the transactional approach, in particular, in the creation of an aircraft building holding company, can be presented as the following functional dependence:

$$
E_{i}=f\left(P_{i}, T C_{i}\right) \rightarrow \mathrm{opt}
$$

where:

$E_{i}$ is the economic efficiency of the process of integration of an aircraft building enterprise for the $i$-th type of the integration;

$P_{i}$ is the profitability of the integration process for the $i$-th type of the integration;

$T C_{i}$ are the total transaction costs of the process of integration of the aircraft building enterprise for the $i$-th type of the integration.

It should be noted that it is necessary to determine the total transaction costs for each variant of integrative transformation; in this case, the variant in which the value of the total transaction costs will be minimal and the profit received from the integration will be maximal will be considered optimal.

It should be borne in mind that depending on a change in the mechanism and type of integration, there will be a change in the costs of the corresponding functional, financial and structural transformations. This is explained by the fact that a more complex organizational structure of the integrative structure will inevitably lead to an increase in the number of connections between the participating 
companies, as well as to complication of the process of development, adoption and implementation of management decisions on economic integration, and, consequently, to an increase in the costs of the integration process. At the same time, it should be remembered that one of the main goals of the integration is to reduce its implementation costs.

2) in the external environment-through the component of state regulation aimed at improving the development of the transactional sector of the national economy, special institutions of ownership/disposition and contracting and infrastructure at the enterprise level, which will help to reduce transaction costs due to more rational use of resources and the solution of the problem of information uncertainty for individual members of the structure.

\section{Research Summary}

\section{Conclusion}

The proposed methodological approaches to minimizing the transaction costs of an aircraft building holding company will ensure the reduction of the respective groups of transaction costs, which will strengthen its competitive position as the main system integrator and, at the same time, an active company of a quasi-integrative aircraft building structure as a novel economic unit of an open model object oriented aircraft production, which ensures, in the context of information asymmetry reduction, the creation of a single interactive information space of common development, production and operation for all participants on the basis of CALS technologies and has a positive effect on reducing transaction costs. In turn, enterprises-centers of competences as system vendors-hand over most of their core, ancillary and servicing operations on the basis of outsourcing and subcontracting, creating, in this case, technological value chains, the effective functioning of which is ensured precisely through optimizing transaction costs arising from the formation of the contracting system when agreements are concluded between participants in the integrative corporate structure.

\section{Acknowledgements}

Investigations of methodological approaches of economic and rational integration and competitive entry of Ukrainian aviation enterprises into the European aviation building space were carried out within the R\&D department of Economics of the European University in the research "Economic Security of Ukraine in the Context of its Participation in European Integration Processes" (state registration number 0114U005432).

The introduction of research findings and proposals in the practice of management will facilitate the formation and development of new forms of economic integration in the aviation industry of Ukraine through the formation of an effective system of economic integration of market-efficient and globally oriented national aviation enterprises and the opportunity to compete with competitive 
players in the global regulatory environment use of advanced methods of corporate governance.

The scientific provisions and results of the research presented in the article are implemented in the practice of management and applied in the activity of economic entities: State Enterprise "Antonov" (introduction certificate \# 500/3949-17 of 10/01/17), PJSC “Ukrainian Scientific-aviation technology research institute” (certificate of implementation $\mathrm{N}^{\circ} 48$ of 01/02/17), LLC "Kievaeroproject" (certificate of implementation $\mathrm{N}^{\circ} 14$ of 19.12.18), which confirms the practical significance of the obtained results.

Modern research and development is not limited to the above methodical approach to minimizing transaction costs when creating an aeronautical holding company. Further research will focus on determining the impact of coronavirus on aviation business activity, on developing effective methods of cost management in times of economic crisis.

\section{Conflicts of Interest}

The authors declare no conflicts of interest regarding the publication of this paper.

\section{References}

Arhiereev, S. I. (2004). State Transactional Policy and Public Transactional Sector under Market Transformation. Scientific Papers of Donetsk National Technical University. Series: Economic, 70, 114-120. (In Russian)

Belchenko, S. V., Halikov, M. A., \& Schepilov, M. V. (2011). Transactional Cost Management of an Integrated Group of Enterprises. Models and Methods. Moscow; Tula: Grif i K. (In Russian)

Bielov, V. (2011). Ukrainian Aviation Industry: Between Stagnation and Corporatization. UNIAN.NET. (In Ukrainian)

https://www.unian.ua/economics/industry/495555-ukrajinskiy-aviaprom-mij-stagnatsi eyu-i-korporatizatsieyu.html

Buriak, P. Yu., \& Livinovska, O. V. (2010). Transformation of Business Structures in the Conditions of Integration. Bulletin of the Lviv State Financial Academy, Economic Sciences, 18, 6-13. (In Ukrainian)

Chukhno, A. A. (2003). Post-Industrial Economics: Theory, Practice and Their Significance for the Country. Kyiv: Lohos. (In Ukrainian)

Coase, R. (1993). Firm, Market and Law (B. Pinsker, transl.). Moscow: Delo LTD. (In Russian)

Kanishchenko, O. L. (2007). International Marketing in the Activity of Ukrainian Enterprises. Kyiv: Znannia. (In Ukrainian)

Kasatov, A. D. (2010). Problems of Development of Integrated Corporate Structures in the Russian Economy. Economic Sciences, 6, 33-39. (In Russian)

Kizim, N. A. (2000). Organization of Large-Scale Economic and Production Systems. Harkov: Biznes Inform. (In Russian)

Krivyakin, K. S. (2012). Features of Production of High-Tech Products. Bulletin of Voronezh State Technical University, 8, 74-76. (In Russian) 
Lisachenko, A. I. (2007). Organizational and Economic Mechanism of Formation of Integrated Corporate Structures. Donetsk: DonSTU. (In Russian)

Mokii, A. (1999). Regional-Sectoral Model of Foreign Economic Integration: Prerequisites for the Implementation Strategy. Lviv: Kooposvita. (In Ukrainian)

Pylypenko, A. A. (2008). Strategic Integration of Enterprises: Theoretical Foundations, Mechanism of Management and Development Modeling. Kharkiv: VD Inzhek. (In Ukrainian)

Pylypenko, A. A., \& Yaldin, I. V. (2016). Organization of Indicative Planning of Sustainable Development of Integrated Business Structure Based on Process-Project Approach. Global and National Problems of Economy, 11, 470-478. (In Ukrainian)

Salikhova, O. B. (2012). High-Tech Productions: From Valuation Methodology to Uplift in Ukraine. Kyiv: SO "Institute of the Economy and Forecasting of the NAS of Ukraine". (In Ukrainian)

Shastitko, A. E. (2010). New Institutional Economic Theory. Moscow: MGU, TEIS. (In Russian)

Shepelenko, O. V. (2012). Optimization of Transaction Costs as a Factor of Economic Development of the Enterprise. In Proceedings from TPEDM'12: International Scientific and Practical Conference "The Theory and Practice of Economic Development Management”(pp. 132-134). Kyiv: LLC “Druk-Info”. (In Ukrainian)

Uilyamson O. I., \&Uinter S. Dzh. (Eds.) (2001). Coase, R. The Nature of the Firm. Moscow: Delo. [In Russian]

Uilyamson, O. I. (1996). Economic Institutions of Capitalism: Firms, Markets, Contractual Relations. Sankt-Peterburg: Lenizdat, SEV Press. (In Russian)

Williamson, O. E. (1979). Transaction-Cost Economics: The Governance of Contractual Relations. Journal of Law Economics, 22, 223-261. https://doi.org/10.1086/466942

Yanchuk, M. B. (2013). Integration of Ukraine's Aeronautical Enterprises in the Face of Globalization Challenges. Kyiv: Osvita Ukrainy. (In Ukrainian)

Yarkaev, I. A. (2007). A Neo-Institutional Approach to Evaluating the Efficiency of the Process of Integration of Industrial Enterprises. Vestnik KGTU, 6, 128-131. (In Russian)

Zamazii, O. V. (2006). Integration and Market Interaction in the Implementation of Enterprise Development Strategy Extended Abstract of Candidate's Thesis. Khmelnytskyi: KNU. (In Ukrainian)

Zverev, Yu. M. (2009). Economic Globalization, Internationalization of Production and Formation of International Production Networks. IKBFU's Vestnik, 1, 23-27. (In Russian) https://doi.org/10.5922/2223-2095-2009-1-4 